\title{
EFEK PEMBERIAN MINYAK ZAITUN (Olive oil) TERHADAP PERUBAHAN PROFIL LIPID PADA TIKUS PUTIH (Rattus novergicus)
}

\author{
Rachmat Faisal Syamsu
}

Fakultas Kedokteran, Universitas Muslim Indonesia

Email : rachmatfaisal.syamsu@umi.ac.id

\begin{abstract}
This research aims to know the effects of olive oil to changes profil lipid (total cholesterol, LDL, HDL, and triglycerides) in the blood of the Rattus novergicus who were given a high cholesterol diet. This research is experimental research methods laboratory with pre and post test control . Homogeneous data and normal data next performed a test of paired t-Test and LSD test. All test data using the 95\% significance level $(p=0.05)$. Conclusion of this research is the olive oil was able to lower the lipid profile, cholesterol 22,61\%, LDL 38,48\%, triglycerides $17.61 \%$ and increase the HDL $25.32 \%$ in the blood of rats high cholesterol diet.
\end{abstract}

Keywords : Olive oil, profil lipid, cholesterol, HDL, LDL, triglycerides.

\section{PENDAHULUAN}

Kolesterol dalam darah merupakan salah satu masalah besar yang dihadapi oleh masyarakat di dunia. Kelebihan kolesterol dalam darah (hiperlipidemia) akan mengakibatkan penyakit jantung dan stroke. Menurut World Health Organization (WHO) dan Organisasi Federasi Jantung Sedunia (World Heart Federation) penyakit jantung saat ini menjadi penyebab utama kematian di negara-negara Asia dan Eropa. Setiap tahun diperkirakan 17,3 juta orang meninggal akibat penyakit kardiovaskular. Sebanyak 11,1 juta diantaranya terjadi akibat penyakit jantung dan 6,2 juta akibat stroke.
Dimana $78 \%$ kematian global akibat penyakit jantung terjadi pada kalangan masyarakat miskin dan menengah. Di negara berkembang angka kematian akibat penyakit jantung meningkat 137 $\%$ pada laki-laki dan $120 \%$ pada wanita, sedangkan di negara maju peningkatannya lebih rendah yaitu $48 \%$ pada laki-laki dan $29 \%$ pada wanita. Oleh karena itu, penyakit jantung menjadi penyebab kematian dan kecacatan nomer satu di dunia. ${ }^{1}$

Di Indonesia pada tahun 2012 penyakit jantung menduduki peringkat pertama yang menyumbang angka kematian. Angka kematian akibat kejadian penyakit jantung kemudian semakin meningkat sebesar $37 \%$ dari 
Efek pemberian minyak zaitun (Olive oil) terhadap perubahan profil lipid pada tikus putih (Rattus novergicus)

angka 16,7\%. Menurut hasil Riset

Kesehatan Dasar (Riskesdas) tahun 2013, menjelaskan bahwa prevalensi penyakit jantung dan stroke semakin meningkat seiring peningkatan umur. ${ }^{17}$

Penyakit jantung dan stroke terjadi karena adanya penyumbatan dan pengerasan dalam pembuluh darah arteri yang disebut arteroskelorosis. Penyumbatan ini disebabkan oleh tingginya kadar kolesterol dalam darah terutama LDL (Low Density Lipoprotein) yang tinggi dalam darah. Low Density Lipoprotein (LDL) disebut juga kolesterol jahat karena kolesterol dalam LDL mudah melekat pada pembuluh darah yang akan menyebabkan penumpukan lemak yang lambat laun akan mengeras membentuk plak (aterosklerosis) dan menyumbat pembuluh darah. Arterosklerosis disebut juga sebagai suatu proses inflamasi kronis yang selain dapat menyebabkan penyakit jantung dan stroke, juga dapat menyebabkan terjadinya sindrom metabolic. ${ }^{2}$

Berbagai upaya telah dilakukan untuk menangani hiperlipidemia, antara lain melalui perubahan gaya hidup seperti terapi diet, yaitu dengan mengkonsumsi serat, ikan, mengurangi daging, mengkonsumsi sumber lemak tak jenuh (MUFA dan
PUFA). Untuk mendukung upaya terapi diet, perlu diikuti upaya penunjang yaitu menurunkan berat badan dan olahraga. Dimana Perubahan gaya hidup ini nantinya akan sangat erat hubungannya dengan peningkatan dan penurunan kadar kolesterol dalam darah. Penurunan kadar kolesterol sebesar 1 $\%$ akan menurunkan risiko penyakit jantung sebesar $2 \%{ }^{3}$

Jika hiperlipidemia tidak dapat dikendalikan dengan diet dan olahraga, maka farmakoterapi merupakan alternatif pilihan selanjutnya. Seringkali dalam terapi secara farmakologi menggunakan obat-obatan sintetis kimia, seperti kelompok statin dan kelompok fibrat. Penggunaan obat sintetis dapat menimbulkan efek samping seperti alergi atau menyebabkan gangguan fungsi organ lain. Untuk itu, perlu dicarikan obat alternatif dari bahan alami. ${ }^{4}$

Didalam Al-Quran Surah At-Tin ayat pertama dikatakan "Wattiini wazzaituun" yang artinya Demi buah Tiin dan buah Zaitun. Allah bersumpah demi buah tiin dan zaitun yang mengundang banyak perhatian peneliti untuk mengkaji maknanya. Dan setelah diteliti ternyata minyak zaitun memiliki kandungan sumber asam 
Efek pemberian minyak zaitun (Olive oil) terhadap perubahan profil lipid pada tikus putih (Rattus novergicus)

lemak tidak jenuh, MUFA (Mono Unsaturated Fatty Acid) yang tinggi. Beberapa penelitian di Mediterania menunjukkan prevalensi penyakit jantung yang rendah pada penduduk di kawasan tersebut, dalam penelitian itu dijelaskan bahwa diet tinggi MUFA dapat menurunkan kadar kolesterol total, LDL, dan trigliserida sebanyak $10 \%$, 14\%, dan 13\%. ${ }^{6}$ Beberapa penelitian juga menyimpulkan bahwa pemberian diet tinggi yang mengandung MUFA (MonoUnsaturated Fatty Acid) tinggi dapat meningkatkan HDL (High Density Lipoprotein) hingga $17 \%{ }^{5}$

Berdasarkan uraian diatas, penulis ingin melakukan penelitian yang berjudul, Efek pemberian minyak zaitun (Olive Oil) terhadap perubahan profil lipid pada tikus putih (Rattus Novergicus), untuk membuktikan apakah minyak zaitun dapat menurunkan profil lipid pada tikus putih jantan yang dibuat diet tinggi lemak dengan menggunakan obat simvastatin sebagai pembanding. Penelitian ini merupakan jenis penelitian eksperimental laboratorium. Tikus putih jantan (Rattus novergicus) digunakan sebagai hewan coba karena termasuk golongan omnivora yang memiliki alat pencernaan dan kebutuhan nutrisi yang hampir sama dengan manusia, memiliki siklus hidup yang relatif panjang, dan dapat mewakili mamalia termasuk manusia. Jenis kelamin jantan digunakan agar tidak terpengaruh oleh siklus hormonal. ${ }^{5}$

\section{METODE PENELITIAN}

\section{Alat dan Bahan Penelitian}

Alat yang digunakan yaitu Kandang pemeliharaan, Kandang perlakuan, Tempat makan dan minum, Sarung tangan (Latex), Sonde lambung, Masker, Dysposible syringe (Terumo, Japan), Kapas,Alat pengukur kolesterol merk human analyzer. Sedangkan bahan yang dipakai yaitu Tikus putih jantan, Minyak Zaitun (Olive Oil) merk AL-AMIR Importir PT.Mitra Bersaudara Jakarta Indonesia, produksi ACEITES DEL SUR COOSUR SA SEVILLASPANYOL. Adapun komposisinya adalah $100 \%$ minyak zaitun, free cholesterol. Minuman dan makanan standar tikus putih jantan yang beredar di pasar berjenis konsentrat produksi Animal Feedmill. Adapun makanan yang diberikan untuk diet hiperlipidemia adalah asupan kuning telur, lemak sapi yang merupakan sumber kolesterol hewani, keduanya mengandung kolesterol tinggi per 100 gramnya sedangkan lemak sapi 
Efek pemberian minyak zaitun (Olive oil) terhadap perubahan profil lipid pada tikus putih (Rattus novergicus)

mengandung asam jenuh yang dapat meningkatkan kadar lipid plasma. ${ }^{7}$

\section{Prosedur Penelitian}

Kelompok I (kontrol negaitf), terdiri dari 6 ekor tikus sehat yang diberi makanan standar tikus dan minum (aquadest steril) tanpa pemberian minyak zaitun (Olive Oil) dan diet tinggi lemak. Di hari pertama sebelum perlakuan dan 14 hari kemudian setelah perlakuan dilakukan pengambilan sampel darah profil lipid.

Kelompok II (kontrol positif), terdiri dan 6 ekor tikus sehat yang diberi makanan standar yang dicampur dengan diet tinggi lemak (lemak kambing / lemak sapi / hati ayam/tepung/ telur puyu 10\%,minyak kelapa 9\%, minyak jagung 1\%) dan minum (aquadest steril). Di hari pertama sebelum perlakuan dan 14 hari kemudian setelah perlakuan dilakukan pengambilan sampel darah profil lipid.

\section{Kelompok III (perlakuan diet tinggi} lemak + minyak zaitun), terdiri dan 6 ekor tikus sehat yang diberi makanan standar yang dicampur dengan diet tinggi lemak (lemak kambing / lemak sapi / hati ayam / tepung / telur puyu $10 \%$, minyak kelapa 9\%, minyak jagung 1\%), minum (aquadest steril), dan minyak zaitun (Olive Oil) 0,36 $\mathrm{ml} / 200 \mathrm{~g}$ secara per oral menggunakan sonde lambung. Di hari pertama sebelum perlakuan dan 14 hari kemudian setelah perlakuan dilakukan pengambilan sampel darah profil lipid.

Kelompok IV (perlakuan diet tinggi lemak + obat simvastatin), terdiri dan 6 ekor tikus sehat yang menjadi kelompok perlakuan yang diberi makanan standar yang dicampur dengan diet tinggi lemak (lemak kambing / lemak sapi / hati ayam / tepung / telur puyu 10\%, minyak kelapa 9\%, minyak jagung $1 \%$ ), minum (aquadest steril), dan larutan simvastatin diperoleh dengan melarutkan 0.18 zat aktif simvastatin ke dalam $5 \mathrm{ml}$ aquades. Larutan simvastatin diberikan dengan menggunakan NGT dan syringe. Di hari pertama sebelum perlakuan dan 14 hari kemudian setelah perlakuan dilakukan pengambilan sampel darah profil lipid.

\section{Pengambilan Sampel Darah}

Prosedur pengambilan sampel darah adalah sebagai berikut : Pengambilan darah vena melalui ekor tikus, dengan cara diinsisi atau digunting Segera setelah darah keluar, darah dimasukkan ke dalam tabung kecil ukuran 8 X $75 \mathrm{~mm}$ sebanyak $1 \mathrm{ml}$.. Sampel darah diperiksa dengan 
Efek pemberian minyak zaitun (Olive oil) terhadap perubahan profil lipid pada tikus putih (Rattus novergicus)

menggunakan alat pengukur profil lipid

Merk Human Analyzer.

\section{HASIL PENELITIAN}

Penelitian ini dilakukan di laboratorium Farmakologi Fakultas Farmasi Universitas Muslim Indonesia dengan jumlah sampel tikus putih sebanyak 24 ekor. Tikus diadaptasikan di laborartorium, lalu kemudian ditimbang agar memenuhi standar sampel dengan berat badan $200 \mathrm{gr}$. Selanjutnya tikus dikelompokkan menjadi 4 kelompok dan dilakukan pengambilan darah kadar kolesterol
LDL, selanjutnya diberi perlakuan sesuai alur penelitian selama 14 hari.

Data yang diperoleh dari hasil penelitian ini kemudian dianalisis secara statistik yaitu, masing-masing di uji Shapiro-Wilk untuk uji normalitas, uji Levene untuk uji homogenitas, uji Paired t-Test untuk mengetahui bagaimana hasil dari perbedaan ratarata (mean) antara kelompok dengan melihat rata-rata sampelnya, dan uji LSD untuk uji perbedaan selisih nilai sebelum dan sesudah perlakuan antara kelompok yang satu dan yang lainnya.

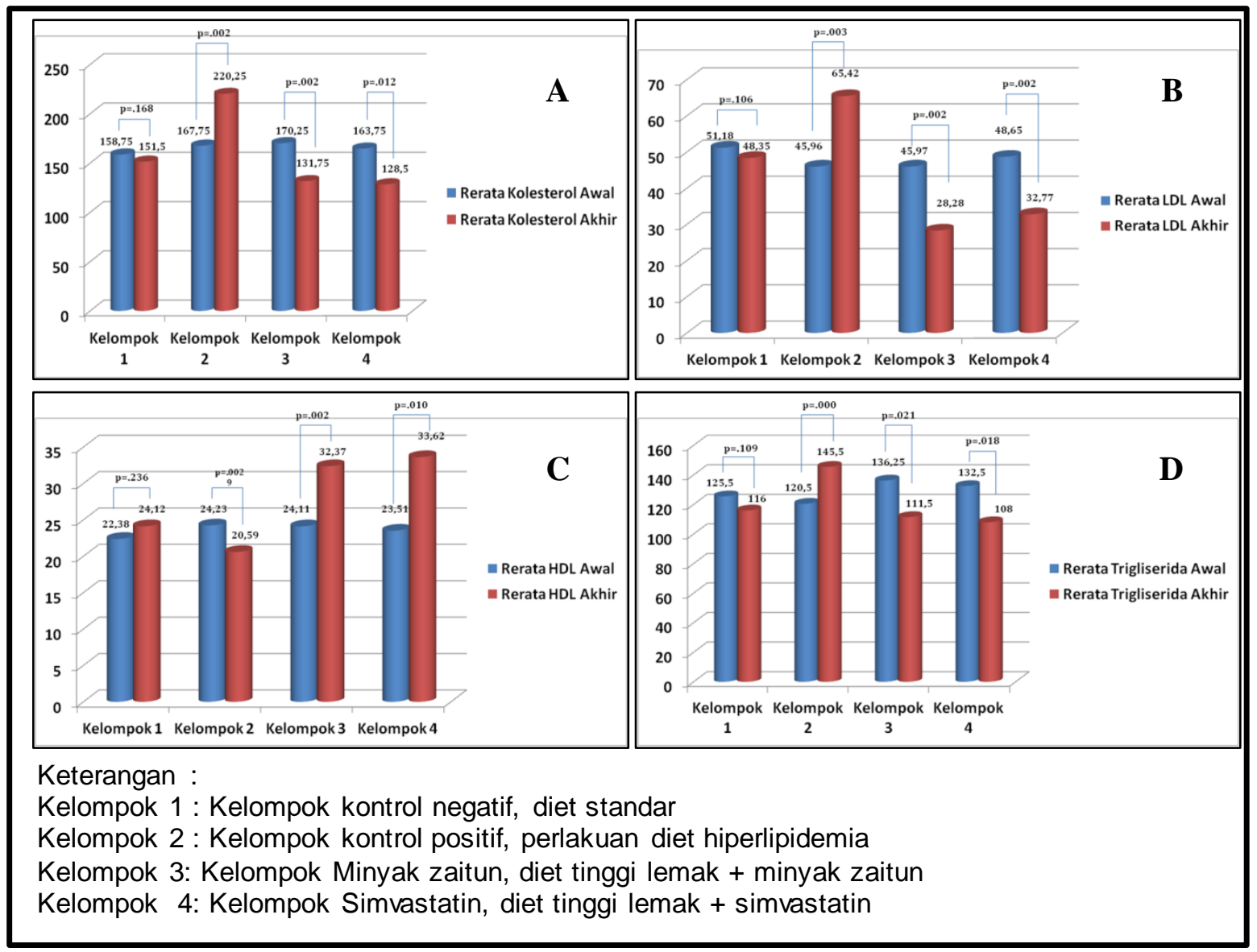

Gambar 1. A: Grafik hasil penelitian kolesterol total tikus putih; B: Grafik hasil penelitian nilai LDLpada tikus putih; C: Grafik hasil penelitian nilai HDL pada tikus putih; D: Grafik hasil penelitian nilai Trigliserid pada tikus putih. 
Efek pemberian minyak zaitun (Olive oil) terhadap perubahan profil lipid pada tikus putih (Rattus novergicus)

\section{PEMBAHASAN}

Penelitian ini dilakukan untuk mengetahui efek pemberian minyak zaitun (Olive Oil) terhadap perubahan profil lipid dalam darah tikus putih jantan (Rattus Novergicus) yang diberi tinggi lemak dengan menggunakan obat simvastatin sebagai pembanding hasil sebelum dan sesudah penelitian. Penelitian ini dibagi menjadi 4 kelompok yaitu, kelompok 1 sebagai kelompok kontrol negatif yang diberi makanan dan minuman standar, kelompok 2 kontrol positif yang diberi diet tinggi lemak, kelompok 3 minyak zaitun yang diberi diet tinggi lemak dan minyak zaitun 0,36 $\mathrm{ml} / 200 \mathrm{grBB} /$ hari, serta kelompok 4 simvastatin yang diet tinggi lemak dan obat simvastatin 0,18 $\mathrm{mg} /$ hari/200grBB.

\section{Pengaruh pemberian minyak zaitun extra virgin terhadap kolesterol total.}

Berdasarkan data yang diperoleh, pemberian minyak zaitun pada kelompok 3 yang diberi diet tinggi lemak setelah diukur kadar kolesterol totalnya mengalami perubahan antara sebelum dan sesudah perlakuan. Dengan nilai rerata sebelum perlakuan adalah 170,25 mg/dl dan setelah perlakuan adalah 131,75 mg/dl, ini berarti minyak zaitun mampu menurunkan 22,61\% kadar kolesterol total tikus putih yang diberi diet tinggi lemak dengan dosis 0,36 ml/200 grBB/hari selama 14 hari. Dari hasil ini dilakukan uji statistik dan diperoleh nilai $p=0.002$ yang artinya adalah tidak sama atau berbeda signifikan sebelum dan sesudah perlakuan. Hasil penelitian ini mendukung penelitian sebelumnya terkait MUFA yang terdapat didalam minyak zaitun oleh Lucock tahun 2007. Dimana dilakukan penelitian pada tikus wistar dengan hasil menunjukkan penurunan rerata kadar kolesterol total sebelum dan sesudah perlakuan sebanyak $13,08 \%$ dengan pemberian minyak zaitun 0,5 $\mathrm{ml} / 100$ gr BB selama 7 hari. $^{18}$ Penelitian oleh Darmanescu tahun 2010, menyatakan bahwa diet tinggi MUFA dapat menurunkan kadar kolesterol total sebanyak 7,4\% dibandingkan diet rendah MUFA. ${ }^{19}$

Studi oleh Hendra et all 2001 menyatakan bahwa efek hipokolesterolemik paa minyak zaitun adalah nyata. $^{8}$ Hal ini dibuktikan dengan ditemukannya penurunan kolesterol di hati yang signifikan pada hewan coba yang diintervensi minyak zaitun yang mengakibatkan kolesterol tidak terakumulasi di dalam hati. Efek hipokolesterolemia dimediasi oleh peningkatan aliran empedu, kolesterol 
Efek pemberian minyak zaitun (Olive oil) terhadap perubahan profil lipid pada tikus putih (Rattus novergicus)

empedu, serta konsentrasi asam empedu. Efek tersebut dibuktikan dengan meningkatnya jumlah asam empedu dan kolesterol pada feces hewan coba. ${ }^{9}$

\section{Regulasi}

kolesterol

berhubungan dengan aktivitas 3hydroxy 3-methylglutaryl (HMG)-CoA reduktase, dimana sintesis kolesterol dikontrol oleh pengaturan HMG-CoA reduktase. Penggunaan substansi yang meghambat hal tersebut sangatlah efektif dalam menurunkan kadar kolesterol. Beberapa penelitian juga memfokuskan pada hewan coba berupa efek senyawa polifenol yang terdapat dalam minyak zaitun terhadap metabolisme kolesterol menunjukkan bahwa aktivitas HMG-CoA reduktase di mikrosom hati berkurang secara signifikan. Hal tersebut sangat bermakna secara klinis karena setiap penurunan 1\% kadar kolesterol dalam darah berarti resiko penyakit jantung dan stroke juga menurun $2-3 \% .^{10}$

Pengaruh pemberian minyak zaitun extra virgin terhadap LDL.

Berdasarkan data yang diperoleh, pemberian minyak zaitun pada kelompok 3 yang diberi diet tinggi lemak setelah diukur kadar LDL nya mengalami perubahan antara sebelum dan sesudah perlakuan. Dengan nilai rerata sebelum perlakuan adalah 45,97 $\mathrm{mg} / \mathrm{dl}$ dan setelah perlakuan adalah 28,28 $\mathrm{mg} / \mathrm{dl}$, ini berarti minyak zaitun mampu menurunkan 38,48\% kadar LDL tikus putih yang diberi diet tinggi lemak dengan dosis 0,36 ml/200 grBB/hari selama 14 hari. Dari hasil ini dilakukan uji statistik dan diperoleh nilai $p=$ 0.002 yang artinya adalah tidak sama atau berbeda signifikan sebelum dan sesudah perlakuan.

Hasil penelitian sebelumnya Sanderson tahun 2005 menyatakan bahwa konsentrasi kadar LDL bergantung kepada laju VLDL (Very Low-Density Lipoprotein). Efek MUFA terhadap penurunan kadar LDL disebabkan karena berubahnya kadar VLDL yang kaya akan trigliserida. Dikatakan juga bahwa penurunan LDL oleh MUFA dapat dihubungkan dengan bertambahnya jumlah reseptor LDL atau berkurangnya konversi IDL menjadi LDL.

Dalam penelitian Veni Hadju et all tahun 2012, menunjukkan penurunan LDL pada sampel manusia yang hiperkolesterolemia setelah pemberian kapsul berisi minyak zaitun 4,8 gr/hari selama 6 minggu. ${ }^{11} \mathrm{Hal}$ ini disebabkan karena intervensi minyak zaitun yang dapat meningkatkan aktifitas antioksidan enzim hepatik seperti catalase, superoxide 
Efek pemberian minyak zaitun (Olive oil) terhadap perubahan profil lipid pada tikus putih (Rattus novergicus)

dismutase, glutathion peroxidase Hydroxytyrosol dan oleuropein yang dapat berperan sebagai scavenging free radical dan menghambat oksidasi low density lipoprotein (LDL). Serta mengakibatkan berkurangnya aktivitas HMG CoA reduktase dan peningkatan eliminasi cholesterol melalui feces lewat jalur penghambatan absorbsi.

Pengaruh pemberian minyak zaitun extra virgin terhadap HDL.

Berdasarkan data yang diperoleh, pemberian minyak zaitun pada kelompok 3 yang diberi diet tinggi lemak setelah diukur kadar HDL nya mengalami perubahan antara sebelum dan sesudah perlakuan. Dengan nilai rerata sebelum perlakuan adalah $24,11 \mathrm{mg} / \mathrm{dl}$ dan setelah perlakuan adalah $32,37 \mathrm{mg} / \mathrm{dl}$, ini berarti minyak zaitun mampu menaikkan 25,32\% kadar kolesterol total tikus putih yang diberi diet tinggi lemak dengan dosis 0,36 m//200 grBB/hari selama 14 hari. Dari hasil ini dilakukan uji statistik dan diperoleh nilai $p=0.002$ yang artinya adalah tidak sama atau berbeda signifikan sebelum dan sesudah perlakuan.

Dari hasil penelitian Dewi Anggraeni tahun 2011 dan Hanna tahun 2012 dengan judul efek pemberian minyak zaitun terhadap koesterol total serta kenaikan HDL terhadap tikus putih yang diberi diet hiperlipid dijelaskan bahwa MUFA dapat meningkatkan kadar HDL lebih tinggi dibandingkan PUFA. ${ }^{12,13}$ Minyak zaitun mengandung MUFA yang cukup tinggi hingga $80 \%$ sehingga dapat meningkatkan kadar HDL dalam darah. Penelitian Marrugat et all 2006 menyatakan bahwa kandungan senyawa fenolik dalam minyak zaitun menentukan efektivitas peningkatan kadar HDL. Senyawa fenolik ini juga diduga dapat masuk kedalam partikel lipoprotein sehingga dapat berkontribusi sebagai antioksidan alami dalam lipoprotein. ${ }^{14}$

Penelitian lain yang dilakukan oleh Mangas-Crus menunjukkan bahwa HDL mengalami peningkatan setelah pembarian minyak zaitun yang kaya akan senyawa fenol, sehingga perlu dilihat kandungan dari minyak zaitun itu sendiri. Penelitian yang dilakukan pada tikus, kelinci hingga manusia ini menunjukkan peningkatan kadar HDL dari kelompok yang diberikan minyak zaitun kaya akan polifenol sebaliknya terhadap minyak zaitun yang miskin polifenol akan menurunkan kadar HDL. Diakhir kesimpulannya disarankan perlunya penelitian lebih lanjut tentang kadar HDL dan minyak zaitu disebabkan karena kadar HDL dalam daerah juga 
Efek pemberian minyak zaitun (Olive oil) terhadap perubahan profil lipid pada tikus putih (Rattus novergicus)

dipengaruhi oleh genetik $50 \%$ dan sisanya oleh faktor lain. ${ }^{15}$

Pengaruh pemberian minyak zaitun extra virgin terhadap Trigliserida.

Berdasarkan data yang diperoleh, pemberian minyak zaitun pada kelompok 3 yang diberi diet tinggi lemak setelah diukur kadar Trigliserida nya mengalami perubahan antara sebelum dan sesudah perlakuan. Dengan nilai rerata sebelum perlakuan adalah 136,25 $\mathrm{mg} / \mathrm{dl}$ dan setelah perlakuan adalah $111,5 \mathrm{mg} / \mathrm{dl}$, ini berarti minyak zaitun mampu menurunkan 17,61\% kadar kolesterol total tikus putih yang diberi diet tinggi lemak dengan dosis 0,36 $\mathrm{ml} / 200$ grBB/hari selama 14 hari. Dari hasil ini dilakukan uji statistik dan diperoleh nilai $p=0.021$ yang artinya adalah tidak sama atau berbeda signifikan sebelum dan sesudah perlakuan.

Penelitian Kris et all tahun 2009 menyatakan diet tinggi MUFA selain dapat menurunkan kadar LDL juga dapat mengakibatkan penurunan kadar trigliserida, karena mayoritas trigliserida diangkut oleh VLDL maka laju produksi dan sekresi trigliserida berbanding lurus dengan VLDL, serta hidrolisis atau pembebasan trigliserida dalam sirkulasi merupakan 2 kunci utama yang menentukan konsentrasi

serum trigliserida dalam tubuh. ${ }^{6}$ Menurut Cicerale 2010, metabolisme trigliserida menentukan kelangsungan metabolisme lipoprotein lain seperti LDL dan HDL. ${ }^{16}$

\section{KESIMPULAN}

Minyak Zaitun (Olive Oil) memiliki kemampuan untuk menurunkan profil lipid (kadar kolesterol total, LDL, dan Trigliserida), serta menaikkan kadar HDL dalam darah tikus putih (Rattus Novergicus) yang diberi diet tinggi lemak.

\section{DAFTAR PUSTAKA}

1. Chesebro JH et all. Thrombolysis in myocardial infarction. (TIMI), 2006.

2. Okada T et all. Antibodies against heat shock protein 60 derived from Helicobacter pylori diagnostic implications in cardiovascular disease. Journal of Auitoimmunity 2007;29:106-15.

3. Anwar BT. Manfaat Diet pada PenanggulanganHiperkolesterolem ia. Surakarta: Repository USU, 2006.

4. Sigit $S$ dan Bijanti R. Kadar Kolesterol Darah pada Tikus Hiperkolesterolemia Setelah Pemberian Kombinasi Diet Telur dengan Asam Lemak Omega-3, Lesitin dan Vitamin E. Media Kedokteran Hewan 2006;(18)2.

5. Orey C. Khasiat Minyak Zaitun Ala Meditreania. Jakarta : Penerbit Hikmah (PT Mizan Publika), 2008.

6. Kris $\mathrm{E}$ et all. High-monounsaturated fatty acid diets lower both plasma 
Efek pemberian minyak zaitun (Olive oil) terhadap perubahan profil lipid pada tikus putih (Rattus novergicus)

cholesterol and triacylglycerol concentrations.Am J Clin Nutr 2009;70:1009-15

7. Widyaningsih W, Mulyono dan Rosidi UE. Efek Ekstrak Etanol Belimbing Manis (Averrhoa carambola L) sebagai Penurun Kadar Kolesterol. Media Farmasi 2007;6:9-14.

8. Hendra et all .Pengaruh pemberian minyak zaitun terhadap kadar kolesterol total dalam darah tikus wistar jantan yang diberi diet hiperlipid. Indonesian journal 2001;62:45.

9. Sanderson $P$ et all. Dietary fatty acids and the immune system. Cell Immunol 2005;164:240-7.

10. Gill JMR et all. Effects of dietary monounsaturated fatty acids on lipoprotein concentrations, compositions, andsubfraction distributions and on VLDL apolipoprotein B kinetics: dosedependent effects on LDL. Am J Clin Nutr 2003;78:47-56.

11. Veni $\mathrm{H}$ et all. Pengaruh minyak zaitun terhadap kolesterol dan trigliserida pada subyek hiperkolesterolemia. Jurnal Kedokteran Unhas 2012.

12. Dewi Anggraeni .Manfaat minyak zaitun terhadap kadar LDL dalam darah tikus putih yang diberi diet hiperlipidemia. Jember : Patologi klinik Fakultas kedokteran gigi, 2011.

13. Hanna K. Manfaat minyak zaitun terhadap kadar Kolesterol Total dalam darah tikus putih jantan yang diberi diet hiperlipidemia. Surakarta : Studi Farmasi UNISMUH., 2012.

14. Marrugat $\mathrm{J}$ et all. Effect of differing phenolic content in dietary olive oils o lipid and LDL oxidation. Eur J Nutr 2006;43:140-7.

15. Merchant AT et all. Carbohydrate intake and $\mathrm{HDL}$ in a multiethnic population. Am J Clin Nutr 2007;85:225-30.

16. Cicerale $S$ et all. Biological activities ofphenolic compounds present in virgin olive oil. Int $\mathrm{J} \mathrm{Mol}$ Sci 2010;11:458-79.

17. http//depkes.go.id/resources/downl oad/general/Hasil\%20Riskesdas\% 202013.pdfdiakses 25 Februari 2016.

18. Lucock M. Nutrition and Genomics: Nutrition and the ascent of humankind. Jon Wiley \& Sons, Inc 2007.P,46-9.

19. Darmanescu D et all. Experimental avaluation ofsome biochemicl parameters after administration offatty acids ethanolamides from extra virgin olive oil in rats. Farmacia 2010;58 (2). 